\title{
Lactic Acid Bacteria and Their Bacteriocins: A Promising Approach to Seafood Biopreservation
}

\author{
Mahdi Ghanbari and Mansooreh Jami \\ Additional information is available at the end of the chapter
}

http://dx.doi.org/10.5772/50705

\section{Introduction}

The growing interest in a correct life style, including alimentation, and the parallel attention on food quality have contributed to orientate consumers towards fishery products which are considered safe, of high nutritional value and capable of influencing human health in a positive way [1]. The diverse nutrient composition of seafood makes it an ideal environment for the growth and propagation of spoilage micro-organisms and common food-borne pathogens [2]. It has been estimated that as much as $25 \%$ of all food produced is lost postharvest owing to microbial activity [1,2]. It has been mentioned that as many as $30 \%$ of people in industrialized countries suffer from a food borne disease each year and in 2000 at least two million people died from diarrhoeal disease worldwide. It is clear that indigenous bacteria present in marine environment as well as the result of post contamination during process are responsible for many cases of illnesses [3,4]. In the last years, the traditional processes applied to seafood like salting, smoking and canning have decreased in favor of mild technologies involving lower salt content, lower cooking temperature and vacuum (VP) or modified atmosphere packing (MAP). The treatments are usually not sufficient to destroy microorganisms and in some cases psychrotolerant pathogenic and spoiling bacteria can develop during the extended shelf-life of these products [2,5]. As several of these products are eaten raw, it is therefore essential that adequate preservation technologies are applied to maintain its safety and quality. Among alternative food preservation technologies, particular attention has been paid to biopreservation to extent the shelf-life and to enhance the hygienic quality, minimizing the impact on the nutritional and organoleptic properties of perishable food products such as seafood [1,6]. Biological preservation refers to the use of a natural or controlled microflora and/or its antimicrobial metabolites to extend the shelf life and improve the safety of food. Lactic acid bacteria (LAB) 
are particularly interesting candidates for this technique [1,2,6,7]. Indeed, they are frequently naturally present in food products and are often strong competitors, by producing a wide range of antimicrobial metabolites such as organic acids, diacetyl, acetoin, hydrogen peroxide, reuterin, reutericyclin, antifungal peptides, and bacteriocins [8-10). Hence, the last two decades have seen intensive investigation on LAB and their metabolites to discover new LAB strains that can be used in food preservation $[1,7,11-13]$.

\section{Bacterial hazards associated with fish and fish products}

From the viewpoint of microbiology, fish and related products are a risky foodstuff group. Pathogenic bacteria associated with seafood can be categorized into three general groups [14]: 1) Bacteria (indigenous bacteria) that belong to the natural microflora of fish (Clostridium botulinum, pathogenic Vibrio spp., Aeromonas hydrophila); 2) Enteric bacteria (non-indigenous bacteria) that are present due to faecal contamination (Salmonella spp., Shigella spp., pathogenic Escherichia coli, Staphylococcus aureus); and 3) bacterial contamination during processing, storage, or preparation for consumption (Bacillus cereus, Listeria monocytogenes, Staphylococcus aureus, Clostridium perfringens, Clostridium botulinum, Salmonella spp.).

Vibrio parahaemolyticus has been isolated from sea and estuary waters on all continents with elevated sea water temperatures. $V$. parahaemolyticus is frequently isolated from fish, molluscs, and crustaceans throughout the year in tropical climates and during the summer months in cold or temperate climates [15]. Fish food associated with illnesses due to consumption of $V$. parahaemolyticus includes fish-balls, fried mackerel (Scomber scombrus), tuna (Thunnus thynnus), and sardines (Sardina pilchardus). These products include both raw and undercooked fish products and cooked products that have been substantially recontaminated $[9,15]$. The most affected by the pathogens are Japan, Taiwan, and other Asian coastal regions, though cases of disease have been described in many countries and on many continents $[9,16]$. Cases of diseases caused by $V$. parahaemolyticus are occasional in Europe. During 20 years, only two cases of gastroenteritis were recorded in Denmark. The interest in this organism has been widened by the finding that similar organisms, $V$. alginolyticus and group of F Vibrio sp. also cause serious disease in humans [17]. V. cholerae is often transmitted by water but fish or fish products that have been in contact with contaminated water or faeces from infected persons also frequently serve as a source of infection $[1,9,19]$. The organism would be killed by cooking and recent cases of cholera in South America have been associated with the uncooked fish marinade seviche (Cilus gilberti) [18].

E. coli is a classic example of enteric bacteria causing gastroenteritis. E. coli including other coliforms and bacteria as Staphylococcus spp. and sometimes enterococci are commonly used as indices of hazardous conditions during processing of fish. Such organisms should not be present on fresh-caught fish $[9,20,21]$. The contamination fish derived food with pathogenic E. coli probably occurs during handling of fish and during the production process [20,22]. An outbreak of diarrhoeal illness caused by ingestion of food contaminated with 
enterotoxigenic E. coli was described in Japan [23]. The illness was strongly associated with eating tuna paste. Brazilian authors [24] isolated 18 enterotoxigenic strains of E. coli (ETEC) from 3 of 24 samples of fresh fish originating from Brazilian markets; 13 of them produced a thermolabile enterotoxin. Infection with verocytotoxin _ producing strains of E. coli (VTEC) after ingestion of fish was recorded in Belgium [25]. An outbreak caused by salted salmon roe contaminated, probably during the production process, with enterohaemorrhagic $E$. coli (EHEC) O157 occurred in Japan in 1998 [22]. The roe was stored frozen for 9 months but it appears that $\mathrm{O} 157$ could survive freezing and a high concentration of $\mathrm{NaCl}$ and retained its pathogenicity for humans [26].

Aeromonas spp. has been recognized as potential foodborne pathogens for more than 20 years. Aeromonads are ubiquitous in fresh water, fish and shellfish and also in meats and fresh vegetables [27]. The epidemiological results so far are, however, very questionable. The organism is very frequently present in many food products, including raw vegetables, and very rarely has a case been reported. Up to $8.1 \%$ of cases of acute enteric diseases in 458 patients in Russia were caused by Aeromonas spp. [28]. In this study, Aeromonas spp. isolates with the same pathogenicity factors were isolated from river water in the Volga Delta, from fish, raw meat, and from patients with diarrhoea. Most Aeromonas spp. isolates are psychrotrophic and can grow at refrigerator temperatures [29]. This could increase the hazard of food contamination, particularly where there is a possibility of crosscontamination with ready-to-eat food products.

Salmonella has been isolated from fish and fishery product, though it is not psychrotrophic or indigenous to the aquatic environment [30]. The relationship between fish and Salmonella has been described by several scientists; some believe that fish are possible carriers of Salmonella which are harbored in their intestines for relatively short periods of time and some believe that fish get actively infected by Salmonella [31]. Most outbreaks of food poisoning associated with fish derive from the consumption of raw or insufficiently heat treated fish and cross-contamination during processing and the U.S. Food and Drug Administration's (FDA) data showed that Salmonella was the most common contaminant of fish and fishery products [31]. The highest Salmonella incidence in fishery products was determined in Central Pacific and African countries while it was lower in Europe and including Russia, and North America [32]. The most common serovar found in the world was $S$. sub Weltvreden [30, 31]. In seafood the commonest serotype encountered was $S$. sub Worthington followed by $S$. sub Weltevreden.

Enterotoxins produced by Staphylococcus aureus are another serious cause of gastroenteritis after consumption of fish and related products. In 3 of 10 samples of fresh fish, higher counts of Staph. aureus were detected than permitted by Brazilian legislation [20,33]. In the southern area of Brazil, Staph. aureus was isolated from $20 \%$ of 175 examined samples of fresh fish and fish fillets (Cynoscion leiarchus). Staph. aureus has also been detected during the process of drying and subsequent smoking of eels in Alaska in 1993 [34]. During the process, S. aureus populations increased to more than $10^{5} \mathrm{CFU} \mathrm{g}^{-1}$ of the analyzed sample, after 2 to 3 days of processing. Subsequent laboratory studies showed that a pellicle (a dried skin-like 
surface) formed rapidly on the strips when there was rapid air circulation in the smokehouse and that bacteria embedded in/under the pellicle were able to grow even when heavy smoke deposition occurred.

In ready-to-eat products, cooking, preservation ingredients, and storage atmosphere inhibit the Gram-negative organisms, resulting in a longer shelf life. Such conditions favor the growth of psychotropic pathogens such as Listeria monocytogenes, allowing them to grow to dangerous levels $[9,35,36]$. L. monocytogenes is a serious threat to consumer health and safety and has been implicated in several deadly outbreaks around the world [1,2]. This organism is halotolerant (up to $28 \% \mathrm{w} / \mathrm{v}$ for short periods), resistant to freezing temperatures, can grow and multiply during refrigeration, where other competing organisms cannot, and is able to survive at low water activity (aw) $[9,14,37]$. L. monocytogenes is widely distributed in the general environment including fresh water, coastal water and live fish from these areas. Contamination or recontamination of seafood may also take place during processing [37-39]. Moreover, L. monocytogenes is a psychrotrophic pathogen with the ability to grow from under 0 to $45^{\circ} \mathrm{C}$ [40]. This ability to grow at storage temperatures means that this bacterium is the main hazard in this kind of product. The pathogenic bacteria L. monocytogenes may grow on fresh seafood. Listeria has been found in farmed rainbow trout [41]. The outbreak of listeriosis related to vacuum packed gravad and cold-smoked fish was described in at least eight human cases for 11 months in Sweden [42]. Cold-smoked and gravad rainbow trout (Oncorhynchus mykiss) and salmon (Salmo salar) have been focused on during recent years as potential sources of infection with $L$. monocytogenes and there are several report on isolation of this food borne pathogen from fish-processing plants environments [14,37,39,43-45]. Seafood treatment is necessary to prevent food-borne illness. However, the pervasive nature of L. monocytogenes makes it difficult for processors to fully eliminate the organism from the environment.

Development of new-generation foods, which are mildly processed, contain few or no preservatives, are packaged in vacuum or modified atmospheres to ensure long shelf life and rely primarily on refrigeration for preservation, has raised concerns of potential increases in botulism risk caused by psychrotrophic nonproteolytic group II Clostridium botulinum [46]. An average of 450 outbreaks of foodborne botulism with 930 cases have been reported annually worldwide [47]. The main habitat of clostridia is the soil but they are also found in sewage, rivers, lakes, sea water, fresh meat, and fish [48,49]. Most critical are the hygienic conditions for handling the product after smoking. There is a risk of botulism due to the growth of $C$. botulinum type $\mathrm{E}$ in smoked fish. The bacterium becomes a hazard when processing practices are insufficient to eliminate botulinal spores from raw fish, particularly improper thermal processing [21]. The growth of C. botulinum and toxin production then depends on appropriate conditions in food before eating: the temperature, oxygen level, water activity, $\mathrm{pH}$, the presence of preservatives, and competing microflora [21]. A problem with $C$. botulinum has been encountered with some traditional fermented fish products. These rely on a combination of salt and reduced $\mathrm{pH}$ for their safety. If the product has insufficient salt, or fails to achieve a rapid $\mathrm{pH}$ drop to below 4.5, C. botulinum can grow. There was no evidence that the fish had been mishandled, but a low salt environment in the 
viscera allowed the bacterium to multiply and to produce toxin. C. perfringens, an important cause of both food poisoning and non-food-borne diarrhoeas in humans, was found in a number of fish owing to contamination with sewage, which is the main source of this organism [21].

\section{Biopreservation}

Seafood products are known to be especially susceptible to both microbiological and biochemical spoilage pathways. The development of effective processing treatments to extend the shelf life of fresh fish products is a must [2]. Additionally, the consumers' demand for high-quality and minimally processed seafood has recently captivated great attention [5, 9]. However, an increase in foodborne illness outbreaks is concomitant with the increase in consumer demand for less processed foods [1]. These trends highlight the importance of studying new microbial stress factors to extend the shelf-life of foods. Until now, approaches to reduce the risk of outbreaks of food poisoning have relied on the search for addition of more efficient chemical preservatives or on the application of more drastic physical treatments such as heating, refrigeration, high hydrostatic pressure (HHP), ionising radiation, pulsed-light, ozone, ultrasound, etc [1,5,50]. In spite of some possible advantage, these types of treatments have many drawbacks and limitation in seafood products: the proven toxicity of many of the commonest chemical preservatives (e.g. nitrites) (3), the alteration of the organoleptic and nutritional properties of seafood by physical treatments due to their delicate nature (e.g. freezing damage, discolouration in case of HHP and ionising radiation) [50,51] and especially recent consumer trends in purchasing and consumption, with demands for healthy seafood products that have been subjected to less extreme treatments (less heat and chill damage), with lower levels of salts, fats, acids, and sugars and/or the complete or the partial removal of chemically synthesized additives $[1,2,7]$. To harmonize consumer demands with the necessary safety standards, traditional means of controlling microbial spoilage and safety hazards in seafood are being replaced by an alternative solution that is gaining more and more attention: "biopreservation technology" $[2,9,13,52,53]$. It consists in inoculating food with microorganisms, or their metabolites, selected for their antibacterial properties and may be an efficient way of extending shelf life and food safety through the inhibition of spoilage and pathogenic bacteria without altering the nutritional quality of raw materials and food products [54, 55].

Lactic acid bacteria (LAB) possess a major potential for use in biopreservation because they are safe to consume, and during storage they naturally dominate the microbiota of many foods. Certain LAB species and strains isolated from seafood have been shown to exert strong antagonistic activity against spoilage and pathogenic microorganisms such as Listeria, Clostridium, Staphylococcus, and Bacillus spp [56-58]. The antagonistic and inhibitory properties of $\mathrm{LAB}$ are due to the competition for nutrients and the production of one or more antimicrobially active metabolites such as organic acids (lactic and acetic acid), hydrogen peroxide, and antimicrobial peptides (bacteriocins) [10]. Certain LAB are able to grow at refrigeration temperatures and are tolerant to modified-atmosphere packaging, low 
$\mathrm{pH}$, high salt concentrations, and the presence of certain additives such as lactic acid, acetic acid, and ethanol. Because of these benefits, LAB can be used as protective cultures to restrict the growth of undesired organisms such as certain spoilage and pathogenic bacteria, with the subsequent benefits in terms of food safety $[9,10,58]$. Moreover, these microorganisms may have additional functional properties and, in some circumstances, they can be beneficial for the consumers [6]. LAB represent the microbial group most commonly used as protective cultures, as they are present in all fermented foods and have a long history of safe use [8]. Safety for the consumers is an aspect of great importance, in particular for some seafood products which are not cooked before consumptions, but also for other types of foods.

\section{The role of lactic acid bacteria in biopreservation technology}

\subsection{Characterization and classification}

Lactic acid bacteria (LAB) encompass a heterogeneous group of microorganisms having as a common metabolic property the production of lactic acid as the majority end - product from the fermentation of carbohydrates [59]. LAB are Gram (+), usually nonmotile, non sporulating, catalase - negative, acid - tolerant, facultative anaerobic organisms and have less than $55 \mathrm{~mol} \% \mathrm{G}+\mathrm{C}$ content in their DNA [60-62]. Except for a few species, LAB members are nonpathogenic organisms with a reputed generally recognized as safe status (GRAS). Taxonomic revisions of these genera and the description of new genera mean that LAB could, in their broad physiological definition, comprise around 20 genera [10]. However, from a practical, food-technology point of view, the following genera are considered the principal LAB: Aerococcus, Carnobacterium, Enterococcus, Lactobacillus, Lactococcus, Leuconostoc, Oenococcus, Pediococcus, Streptococcus, Tetragenococcus, Vagococcus, and Weissella [61]. The classification of lactic acid bacteria into different genera is largely based on morphology, mode of glucose fermentation, growth at different temperatures, configuration of the lactic acid produced, ability to grow at high salt concentrations, and acid or alkaline tolerance [62, 63]. An important characteristic used in the differentiation of the LAB genera is the mode of glucose fermentation under standard conditions. In this regard, the accepted definition is that given by Hommes and Vogel [64]: obligately homofermentative LAB are able to ferment hexoses almost exclusively to lactic acid by the Embden-Meyerhof-Parnas (EMP) pathway while pentoses and gluconate are not fermented as they lack phosphoketolase; facultatively heterofermentative LAB degrade hexoses to lactic acid by the EMP pathway and are also able to degrade pentoses and often gluconate as they possess both aldolase and phosphoketolase; finally, obligately heterofermentative degrade hexoses by the phosphogluconate pathway producing lactate, ethanol or acetic acid and carbon dioxide; moreover, pentoses are fermented by this pathway [62]. Several strains of groups 1 and 2 and some of the hetero fermentative group 3 are either used in fermented foods, but group 3 are also commonly associated with food spoilage. (For a more detailed discussion concerning the metabolic pathways, see [59]. 


\subsection{Antimicrobial components from LAB}

\subsubsection{Bacteriocins}

Bacteriocins are ribosomally synthesized peptides, that exert their antimicrobial activity against either strains of the same species as the bacteriocin producer (narrow range), or to more distantly related species (broad range) $[1,2,7]$. It has been estimated that between $30 \%$ and $99 \%$ of all bacteria and archaea produce bacteriocins; their production by LAB is very significant from the point of view of their potential applications in food systems and thus, unsurprisingly, these have been most extensively investigated $[6,10,12,60,65,66]$. It has been noted that the activity of bacteriocins is frequently directed against bacteria that are related to the bacteriocin - producing strain or against bacteria found in similar environments [67]. It has also been noted that some bacteriocins can also play a role in cell signaling. Microorganisms that produce bacteriocins also possess immunity mechanisms to confer self - protection, that is, to protect bacteriocin producers from committing "suicide" [10,68,69]. Besides concern about antibiotic resistance, increasing consumer awareness of potential health risks associated with chemical preservatives has increased interest in bacteriocins. Bacteriocins are naturally produced so they are more easily accepted by consumers [54]. Bacteriocins are usually classified combining various criteria. The main ones being the producer bacterial family, their molecular weight and finally their amino acid sequence homologies and/or gene cluster organization $[59,70]$. Based on a relatively recent approach $[69,71,72]$ bacteriocins produced by LAB have been categorized into two major classes: the lanthionine - containing bacteriocins or lantibiotics (class I) and the largely unmodified linear peptide antimicrobials (class II).

\subsubsection{Organic acid production}

An important role of meat LAB starter cultures is the rapid production of organic acids; this inhibits the growth of unwanted flora and enhances product safety and shelf life. The types and levels of organic acids produced during the fermentation process depend on the LAB strains present, the culture composition, and the growth conditions [74]. Fermentation of the carbohydrates, glucose, glycogen, glucose-6-phosphate and small amounts of ribose, in meat and meat products, produces organic acids by glycolysis (Embden-Meyerhof Parnas pathway, EMP pathway) or the Hexose Monophosphate, HMP pathway. L (+) lactic acid is more inhibitory than its D (-) counterpart [68]. The antimicrobial effect of organic acids lies in the reduction of $\mathrm{pH}$, and in the action of undissociated acid molecules [75]. It has been proposed that low external $\mathrm{pH}$ causes acidification of the cytoplasm. The lipophilic nature of the undissociated acid allows it to diffuse across the cell membrane collapsing the electrochemical proton gradient. Alternatively, cell membrane permeability may be affected, disrupting substrate transport systems [72]. The LAB in particular are able to reduce the $\mathrm{pH}$ to levels where putrefactive (e.g. clostridia and pseudomonads), pathogenic (e.g. Salmonella s and Listeria spp.) and toxinogenic bacteria (Staphylococcus aureus. Bacillus cereus, Clostridium botulinum) will be either inhibited or killed [7]. Also, the undissociated acid, on account of its fat solubility, will diffuse into the bacterial cell, thereby reducing the intracellular $\mathrm{pH}$ and 
slowing down metabolic activities, and in the case of Enterobacteriaceae such as E. coli inhibiting growth at around $\mathrm{pH}$ 5.1.

\subsubsection{Other antimicrobials of $L A B$}

Hydrogen peroxide is produced from lactate by LAB in the presence of oxygen as a result of the action of flavoprotein oxidases or nicotinamide adenine dinucleotide (NADH) peroxidise [76]. The antimicrobial effect of $\mathrm{H}_{2} \mathrm{O}_{2}$ may result from the oxidation of sulfhydryl groups causing denaturing of a number of enzymes, and from the peroxidation of membrane lipids thus increasing membrane permeability [8]. Most undesirable bacteria such as Pseudomonas spp. and $\mathrm{S}$. aureus are many times sensitive to $\mathrm{H}_{2} \mathrm{O}_{2}$. Carbon dioxide $\left(\mathrm{CO}_{2}\right)$ is mainly produced by heterofermentative LAB. $\mathrm{CO}_{2}$ plays a role in creating an anaerobic environment which inhibits enzymatic decarboxylations, and the accumulation of $\mathrm{CO}_{2}$ in the membrane lipid bilayer may cause a dysfunction in permeability [8]. $\mathrm{CO}_{2}$ can effectively inhibit the growth of many food spoilage microorganisms, especially Gramnegative psychrotrophic bacteria [77]. Diacetyl, an aroma component, is produced by strains within all genera of LAB by citrate fermentation. It is produced by heterofermentative lactic acid bacteria as a by-product along with lactate as the main product [8]. Diacetyl is a high value product and is extensively used in the dairy industry as a preferred flavour compound. Diacetyl also has antimicrobial properties. Diacetyl was found to be more active against gram-negative bacteria, yeasts, and molds than against gram-positive bacteria. Diacetyl is thought to react with the arginine-binding protein of gram-negative bacteria and thereby interfering with the utilization of this amino acid [78].

\section{LAB in fish and fish products}

$\mathrm{LAB}$ are not considered as genuine microflora of the aquatic environment, but certain genera, including Carnobacterium, Lactobacillus, Enterococcus, and Lactococcus, have been found in fresh and sea water fresh fish [61,63,79-83]. The number of lactobacilli in the gastrointestinal tract of Arctic char was smaller in those reared in sea water than in fresh water, while the number of Leuconostoc and enterococci remained the same [84]. It is well documented that lactobacilli are part, not dominant, of the native intestinal microbiota of Arctic charr (Salvelinus alpinus L.), Atlantic cod, Atlantic salmon (Salmo salar L.), and brown trout (Salmo trutta) $[82,85]$. Several studies have shown the presence of other lactic acid bacteria, specially carnobacteria such as Carnobacterium maltaromaticum and Carnobacterium divergence within the intestinal content of salmonid species like Arctic charr (Salvelinus alpinus), Atlantic salmon (Salmo salar), rainbow trout (Oncorhyncus mykiss) [63,86-89], Atlantic cod [89], common wolffish (Anarhichas lupus L.) [85], brown trout [82] and also wild pike [63,82]. Bacteria of the genus Enterococcus have been isolated from the intestine of common carp (Cyprinus carpio) and brown trout [80,82].

LAB dominating in spoiled vacuum-packaged cold-smoked fish products include the genera of Lactobacillus, Leuconostoc, Lactococcus and Carnobacterium [9]. Magnússon \& Traustadóttir 
[91] reported the complete dominance of homofermentative lactobacilli in vacuumpackaged cold-smoked herring. In vacuum packaged cold-smoked salmon and herring, Lactobacillus curvatus has been found in majority together with lower numbers of Lactobacillus sakei, Lactobacillus plantarum, Lactococcus spp. and Leuconostoc mesenteroides [58,]. Paludan-Müller, Huss, \& Gram [92] identified Carnobacterium piscicola as the dominant microorganism isolated from spoiled vacuum-packaged cold-smoked salmon. Leroi et al. [93] also isolated carnobacteria during the first stage of storage of vacuum-packaged coldsmoked salmon, whereas Lactobacillus farciminis, Lactobacillus sakei, and Lactobacillus alimentarius were isolated at advanced storage times. Other studies have also confirmed that most bacteria in vacuum-packaged "gravad" fish products stored at refrigeration temperatures are carnobacteria [94] and L. sakei, and to a lesser extent Leuconostoc spp., L. curvatus, and Weissella viridescens [95]. Gancel et al [90] have isolated 78 strains belonging to the genus Lactobacillus from fillets of vacuum packed smoked and salted herring (Clupea harengus). LAB has been found to occur in marinated herring, herring fillets and cured stockfish [58]. In marinated or dried fish, the lactic acid bacteria flora maybe quite diverse since the presence of Lactobacilli and Pediococci has been reported [90]. Thai fermented fishery products were screened for the presence of LAB by Ostergaard et al. [96]. LAB was found to occur in the low salted fermented products in the range of $10^{7}-10^{9} \mathrm{cfu} / \mathrm{g}$. The high salt product "hoi dorng" had a lower LAB count of $10^{3}-10^{5} \mathrm{cfu} / \mathrm{g}$. Olympia et al [97] have isolated $10^{8} \mathrm{LAB} / \mathrm{g}$ from a Philippine low salt rice-fish product burong bangus. Several studies have been mentioned that some species of Carnobacteriuim such as $C$. divergens and C. maltaromaticum are present in seafood and are able to grow to high concentrations in different fresh and lightly preserved products such as modified atmosphere-packed (MAP) [98-100], chilled MAP [101,102], high-pressure processing treated seafood products [103] and vacuum-packed cold smoked or sugar-salted ('gravad') seafood [53,93,95]. These studies clearly highlight the ability of LAB fish isolates to grow on different harsh condition rather than other organisms. Obviously many investigation have been shown that carnobacteria are common in chilled fresh and lightly preserved seafood, but at higher storage temperatures $\left(15-25^{\circ} \mathrm{C}\right)$ other species could be dominate the spoilage microbial community of seafood.

\section{Application of LAB in seafood}

Treating catfish fillets with of $0.50 \%$ sodium acetate, $0.25 \%$ potassium sorbate with $2.50 \%$ lactic acid culture completely inhibited growth of Gram negative bacteria, improved catfish odor and appearance during 13 days storage [110]. Einarsson \& Lauzon [111] treated shrimps with various bacteriocins from lactic acid bacteria and reported shelf life extension except carnocin UI49. Total mesophilic and psychotropic bacteria and MRS counts of the samples treated with carnocin UI49 were not different than those of controls at $4.5^{\circ} \mathrm{C}$. In a study with five strains of lactic acid bacteria (four Lactobacillus and one Carnobacterium) on fermented salmon fillets, L. sake LAD and L. alimentarius BJ33 was regarded as suitable starters for fermentation of salmon fillets [112] based on starter growth (increase of more than $1 \log$ in 3 days) and acidification of muscle (e.g. $\mathrm{pH}$ reduction of approximately 0.7 
units in 5 days) as well as sensory evaluation. Kisla \& Ünlütürk [113] studied the microbial shelf life of rainbow trout treated with nisin-containing aqueous solution of Lactococcus lactis subsp. lactis NCFB 497and lactic acid. They reported the dipping of rainbow trout fillets into a lactic culture did not prolonged the shelf life due to the low inoculum level and type of lactic culture used. Elotmani \& Assobhei [114] evaluated the inhibition of the microbial flora of sardine by using nisin and a lactoperoxidase system (LP), observing the efficiency of the nisin-LP combination in inhibiting fish spoilage flora. In another study growth of $L$. monocytogenes was significantly inhibited $(\mathrm{P}<0.05)$ by $L$. sakei Lb706 in rainbow trout fillets stored under vacuum at $4^{\circ} \mathrm{C}$ during 10 days of storage while bacteriocin negative Lb706-B did not affect the growth of L. monocytogenes. In the presence of the sakacin A-producing strain of L. sakei (Lb706), the growth of L. monocytogenes was significantly inhibited $(\mathrm{P}<0.05)$ in the first 3 days of storage at $10^{\circ} \mathrm{C}$, after which its count increased to $10^{7} \mathrm{CFU} \mathrm{g}{ }^{-1}$ [115]. Altieri et al. [106] succeeded in inhibiting Pseudomonas spp. and P. phosphoreum in VP fresh plaice fillets at low temperatures by using a Bifidobacterium bifidum starter, and extending the shelf-life, especially under MAP. Bifidobacteria combined with sodium acetate (SA) extended refrigerated shelf-life of catfish fillets at $4^{\circ} \mathrm{C}$ [116]. The application of two Lactobacillus sakei CECT 4808 and L. curvatus CECT 904T protective cultures on refrigerated vacuum-packed rainbow trout (Oncorhynchus mykiss) fillets resulted in extension of shelf-life by 5 days by significantly improved in the counts of all microbiological spoilage indicator organisms (Enterobacteriaceae, Pseudomonas spp., H2S-producing bacteria, yeasts and moulds) and also significantly improved in all examined chemical parameters and off-odour [117].

Under biopreservation, combined coating of Lactobacillus casei DSM 120011 and Lactobacillus acidophilus 1M in Streptomces sp. NIOF metabolites, played effective role in lowering the biochemical and microbiological changes, extended shelf-life and safety of stored fish under low temperature as reported by Daboor \& Ibrahim [118]. Tahiri et al. [119] suggest that selection of protective strains to improve the sensory quality of seafood products should focus on specific spoilage microorganism's inhibition. This approach was chosen by Matamoros et al., [120] who have isolated seven strains from various marine products on the basis of their activity against many spoiling and pathogenic, Gram positive and Gram negative marine bacteria. Among strains, two Le. gelidum, and two Lc. piscium demonstrated promising effect in delaying the spoilage of tropical shrimp and of VP CSS. However, no correlation with the classical quality indices measured was evidenced. A recent study demonstrated that this protective effect could be due to the inhibition of B. thermosphacta identified as one of the major spoiler organisms in cooked shrimp stored under MAP [121]. The inoculation of Tilapia (Oreochromis niloticus) fillets with Lactobacillus casei DSM 120011 and Lactobacillus acidophilus $1 \mathrm{M}$ at $2 \%$ concentration decreased both total volatile basic nitrogen (TVB-N), trimethylamine nitrogen (TMA-N) and thiobarbituric acid (TBA) values and improved the biochemical quality criteria, microbial aspects and safety of frozen fish fillets during 45 and 90 days storage. [122].

For Shirazinejad et al. [123] 2.0\% lactic acid combined with nisin indicated the highest reduction in population of Pseudomonas spp. and $\mathrm{H}_{2} \mathrm{~S}$ producing bacteria during storage 
time of Chilled Shrimp. Fall et al. [121] evidenced the in situ inhibition of B. thermosphacta, a major spoiling bacterium, by L. piscium that could explain the protective effect observed in shrimp. Additionally, those strains also showed an inhibitory effect on L. monocytogenes [124] and Staph. aureus. Recently, Sudalayandi \& Manja [109] succeeded to preserve fresh fish through controlling spoilage bacteria and amines of Indian mackerel fish chank for two days at $37^{\circ} \mathrm{C}$ by inoculating them with different strains of LAB such as Pediococcus acidilactici, Pediococcus pentosaceous, Streptococcus thermophilus, Lactococcus lactis, Lactobacillus plantarum, Lactobacillus acidophilus and Lactobacillus helveticus. Using bacteriocin-like metabolite producer and non-producer strains of Pediococcus spp. [125] only slightly improved sensory quality of Horse Mackerel during cold storage. It was concluded that Pediococcus strains used in this study were not proper for preserving horse mackerel fillets especially at low storage temperatures. EntP-producing enterococci isolated from farmed turbot, under a spray-dried format exhibited antilisterial, antistaphylococcal, and antibacilli activities in turbot fillets either vacuum-packaged or subjected to modified-atmosphere packaging [2].

LAB Protective cultures have not been applied in many other seafood products except for cold smoked salmon (CSS), as they are normally flora of such products at the end of storage, and L. monocytogenes control. The effectiveness of bacteriocins to control growth of $L$. monocytogenes in vacuum packed cold smoked salmon has also been demonstrated by several researchers. Among them, Sakacin P has been found to be very potent against $L$. monocytogenes and is one of the most extensively studied bacteriocins [126-131]. Leroi et al. [132] succeeded in increasing the sensory use-by-date of CSS slices by inoculating them with strains of Carnobacterium sp. However the results varied depending on the batch treated. Addition of nisin to $\mathrm{CO}_{2}$ packed cold smoked salmon resulted in a 1 to $2 \log _{10}$ reduction of $L$. monocytogenes [11]. Using a strain of C. maltaromaticum, Paludan-Müller et al. [92] only slightly extended the shelf-life of smoked salmon. Budu-Amoako et al. [133] tested nisin combined with heat as anti Listerial treatment in cold- packed lobster meat, finding decimal reductions of inoculated L. monocytogenes of 3 to 5 logs, whereas heat or nisin alone resulted in decimal reductions of 1 to 3 logs.

Duffes et al. [65] isolated C. divergens and C. maltaromaticum strains that exhibited listericidal activity in a model experiment with cold-smoked fish. They found that C. piscicola V1 inhibited L. monocytogenes by the in situ production of bacteriocins in vacuum-packed coldsmoked salmon stored at $4^{\circ} \mathrm{C}$ and $8^{\circ} \mathrm{C}$. In contrast, another related species, namely, $\mathrm{C}$. divergens V41 and its divercin V41, only exhibited a bacteriostatic effect on the target microorganism. Two strains of $C$. maltaromaticum isolated from CSS demonstrated their efficiency to limit the growth of L. monocytogenes in VP CSS during 31 days of storage at $5^{\circ} \mathrm{C}$ [134]. In a study using vacuum-packed cold smoked rainbow trout, the combination of nisin and sodium lactate injected into smoked fish decreased the count of L. monocytogenes from 3.3 to $1.8 \log _{10}$ over 16 days of storage at $8^{\circ} \mathrm{C}$ [135]. Sakacin P was added to vacuum-packed cold smoked salmon, a lightly processed high-fat (15-20\%) product, together with a sakacin P-producing L. sakei culture in order to study the effect on the growth of L. monocytogenes. In 
this product, the combination of purified sakacin $\mathrm{P}$ and a live culture was found to be bactericidal against L. monocytogenes. The addition of sakacin $\mathrm{P}$ alone inhibited the growth of L. monocytogenes on this product for about 1 week [126]. Silva et al. [136] used a bacteriocinproducing Carnobacterium strain under a spray-dried format. This strain survived the process and retained antilisterial ability, although it lost activity against other Gram-positive targets such as Staph. aureus. Some authors have evaluated the antimicrobial activity of nisin combined with other bacteriocins. Bouttefroy \& Milliere [137] tested combinations of nisin and curvaticin 13 produced by L. curvatus SB13 for preventing the regrowth of bacteriocinresistant cells of L. monocytogenes, finding that this combination induced a greater inhibitory effect than the use of a single bacteriocin. Aasen et al. [131] studied the interactions of the bacteriocins sakacin P and nisin with food constituents in cold-smoked salmon, chicken cold cuts, and raw chicken. They stated that owing to the amphiphilic nature of these peptides, they can be adsorbed to food macromolecules and undergo proteolytic degradation, which may limit their use as preservation agents. More than $80 \%$ of the added sakacin $\mathrm{P}$ and nisin were rapidly adsorbed by proteins in the food matrix that had not been heat-treated, less than $1 \%$ of the total activity remaining after 1 week in cold- smoked salmon. In heat-treated foods, they found that, bacteriocin activity was stable for more than 4 weeks. No important differences were observed between sakacin $\mathrm{P}$ and nisin, but less nisin was adsorbed by muscle proteins at low $\mathrm{pH}$. The growth of L. monocytogenes was completely inhibited for at least 3 weeks in both chicken cold cuts and cold-smoked salmon by the addition of sakacin $\mathrm{P}$ $(3.5 \mu / g)$, despite proteolytic degradation in the salmon.

In the presence of the bacteriocinogenic strain C. maltaromaticum CS526 isolated from surimi, the population of L. monocytogenes in CSS decreased from $10^{3}$ to $50 \mathrm{CFU} \mathrm{g}{ }^{-1}$ after 7 days at $4^{\circ} \mathrm{C}$ [138]. This activity could be linked to the production of the bacteriocin piscicocin CS526, since a non-bacteriocin producing strain had a lower effect on the growth of the pathogenic bacteria $[138,139]$. The growth of the protective Carnobacterium strains did not modify the sensory characteristic of the product. One of these strains showing the strongest inhibition activity produces a bacteriocin, named Carnobacteriocin B2 that was involved in the antilisterial activity [105]. Three strains of bacteriocin producing Carnobacterium have been tested with the agar diffusion test method against a wide collection of L. monocytogenes (51 strains) isolated from seafood. All of the Listeria strains were sensitive. The inhibition was confirmed in co-culture with a mix of L. monocytogenes strains in sterile CSS [140]. One of these strains, $C$. divergens $\mathrm{V} 41$ showed its ability to maintain L. monocytogenes at the initial inoculating level of $20 \mathrm{CFU} \mathrm{g}{ }^{-1}$ during 28 days of storage at $4^{\circ} \mathrm{C}$ and $8^{\circ} \mathrm{C}$. The effect of this strain on sensory characteristics and physico-chemical parameters revealed that it did not spoiled the product [56].

A bacteriocinogenic strain of $L$. sakei isolated from CSS allowed a 4 log reduction of Listeria innocua after 14 days of storage at $4^{\circ} \mathrm{C}$. A reduction of $2 \log$ units after $24 \mathrm{~h}$ at $5^{\circ} \mathrm{C}$ was also demonstrated with that strain in CSS juice towards L. monocytogenes [141]. Mix of bacteriocin-producing LAB like L. casei, L. plantarum and C. maltaromaticum were successfully used to limit the growth of L. innocua in CSS [142]. C. maltaromaticum had no 
effect on the inhibition of the Gram positive spoilage bacteria B. thermosphacta in cooked shrimps [143]. The anti-listerial activity of 3 LAB strains used individually or as co-cultures was assayed on cold-smoked salmon artificially contaminated with L. innocua and stored under vacuum at $4^{\circ} \mathrm{C}$ [142]. The association of L. casei $\mathrm{T} 3$ and L. plantarum PE2 was the most effective, probably due to a competition mechanism against the pathogen. In their study Tomé et al. [144] have also selected a strain of Enterococcus faecium among five bacteriocinogenic LAB strains for its ability to induce a decrease of the population of $L$. innocua inoculated in CSS. However in these studies the inhibition activities were not confirmed on L. monocytogenes. For Matamoros et al. [145] two LAB strains, Lactococcus piscium EU2241 and Leuconostoc gelidum EU2247 were efficient to limit the growth of both pathogenic bacteria L. monocytogenes and $S$. aureus in a challenge test in cooked shrimp stored under VP from 2 to $3 \log \mathrm{CFU} \mathrm{g}{ }^{-1}$ units after 4 weeks at $8^{\circ} \mathrm{C}$ followed by 1 week at $20^{\circ} \mathrm{C}$. The strain of Leuconostoc produced a bacteriocin-like compound but its activity was slight lower than the Lactococcus strain that was non-bacteriocinogenic. In another study, the application of $C$. divergens M35 towards L. monocytogenes in CSS resulted in a maximal decrease of $3.1 \log \mathrm{CFU} \mathrm{g}{ }^{-1}$ of the pathogenic bacteria after 21 days of storage at $4^{\circ} \mathrm{C}$ whereas a non bacteriocinogenic strain had no effect [119].

\section{Conclusion and future prospective}

The presence of LAB in many processed seafood product is now well documented and the bio-protective potential of many strains and/or their bacteriocin has been highlighted in the last years. In situ production is readily cost-effective provided that the bacteriocin producers are technologically suitable. To date, only nisin and pediocin PA - 1 have been applied commercially in food applications where they are used to protect against spoilage and pathogenic organisms. However, other bacteriocins could be at least as effective for food processors as it is possible to apply them with hurdle approaches, particularly in light of consumer demands for minimally processed, safe, preservative - free foods. Control of pathogenic bacteria has widely focused on L. monocytogenes considered as the main risk in ready-to-eat seafood. However, in these minimally processed products, the new combination of hurdles can give selective advantages to enhance food safety and quality, particularly effective against other pathogenic bacteria like clostridia, vibrio or staphylococci. These goals can be facilitated through the incorporation of live bacteriocin producing strain(s) or through the use of bacteriocins as concentrated preparations, either through direct addition to the seafood or in an immobilized form on packaging as well as in conjunction with other factors such as high pressure or pulse electric fields, to achieve more effective preservation of foods. The great results obtained with protective culture, bacteriocins for improving safety and quality of seafood products clearly indicate that the application of LAB protective culture and/or their bacteriocins in seafood product can suggest several important benefits; 1) extended shelf life of seafood during storage time, 2) decrease the risk for transmission of foodborne pathogens in lightly preserved seafood products, 3) ameliorate the economic losses due to seafood spoilage, 4) reduce the application of chemical preservatives and drastic physical treatments such as heating, 
refrigeration, etc. causing better preservation nutritional quality of food, 5) good option for industry due to cost effective way and finally 6) a good response to consumer demands for minimally processed, safe, preservative - free foods. At present the new techniques and disciplines emerging in the post - genomic era, such as genomics, proteomics, metabolomics, and system biology, open new avenues for interpretation of biological data. In combination with classical and molecular techniques, these new methods will be invaluable in the rational optimization of LAB function in order to obtain safer traditional and new seafood products.

\section{Author details}

Mahdi Ghanbari* and Mansooreh Jami

University of Zabol, Faculty of Natural Resources, Department of Fishery; Zabol, Iran

BOKU - University of Natural Resources and Life Sciences, Department of Food Sciences and Technology, Institute of Food Sciences, Vienna, Austria

\section{References}

[1] Cortesi ML, Panebianco A, Giuffrida A, Anastasio A (2009) Innovations in seafood preservation and storage. Veterinary Research Communications.; Supplement 1: p. S15S23.

[2] Campos A, Castro P, Aubourg SP, Velázquez JB (2012) Use of Natural Preservatives in Seafood. In McElhatton A, Sobral. Novel Technologies in Food Science, Integrating Food Science and Engineering Knowledge Into the Food Chain.: (c) Springer Science+Business Media;. p. 325-360.

[3] Feldhusen F (2000) The role of seafood in bacterial foodborne diseases. Method. Microbiol. 2: 1651-1660.

[4] ICMSF (2011) Fish and Seafood Products. In International Commission on Microbiological Specifications for Foods (ICMSF). Microorganisms in Foods.: Springer Science+Business Media, LLC. p. 107-133.

[5] Alzamora S, Welti-Chanes J, Guerrero S (2012) Rational Use of Novel Technologies:A Comparative Analysis of the Performance of Several New Food Preservation Technologies for Microbial Inactivation. In McElhatton A, Sobral PJA(). Novel Technologies in Food Science, Integrating Food Science and Engineering Knowledge Into the Food Chain.: (C) Springer Science+Business Media, LLC.

[6] Soomro AH, Masud T, Anwaar K (2002) Role of lactic acid bacteria (LAB) in food preservation and human health-A review. Pak. J. Nut. 1: 20-24.

[7] Gálvez A, Abriouel H, López R, Omar N (2007) Bacteriocin-based strategies for food biopreservation. Int. J. Food Microbiol. 120: 51-70.

\footnotetext{
${ }^{*}$ Corresponding Author
} 
[8] Holzapfel WH, Geisen R, Schillinger U (1995) A review paper: biological preservation of foods with reference to protective cultures, bacteriocins and food-grade enzymes. Int. J. Food Microbiol. 24: p. 343-362.

[9] Calo-Mata P, Arlindo S, Boehme K, Miguel T, Pascola A, Barros-Velazquez J (2008) Current Applications and Future Trends of Lactic Acid Bacteria and their Bacteriocins for the Biopreservation of Aquatic Food Products. Food Biopro. Tech.1: 43-63.

[10] Collins B, Cotter P, Hill , Paul Ross R (2010) Applications of Lactic Acid Bacteria Produced Bacteriocins. In Mozzi F, Raya R, GM V. Biotechnology of Lactic Acid Bacteria Novel Applications.: Blackwell Publishing. 89-109.

[11] Nilsson L (1997) Control of Listeria monocytogenes in cold-smoked salmon by biopreservation: Danish Institute for Fisheries Research and The Royal Veterinary and Agricultural University of Copenhagen, Denmark, Ph. D Dissertation.

[12] Cleveland J, Montville T, Nes I, Chikindas M (2001) Bacteriocins: Safe, natural antimicrobials for food preservation. Int. J. Food Microbiol. 71: p. 1 - 20.

[13] Dortu C, Thonart P (2009) Bacteriocins from lactic acid bacteria: interest for food products biopreservation. Biotech. Agr. Society Environ. 13: p. 143-154.

[14] Beaufort A, Rudelle S, Gnanou-Besse N, Toquin MT, Kerouanton A, Bergis H (2007). Prevalence and growth of Listeria monocytogenes in naturally contaminated cold-smoked salmon. Lett. Appl. Microbiol. 44: 406-411.

[15] Baffone W, Pianei A, Bruscolini F, Barbieri E, Cierio B (2000) Occurrence and expression of virulence-related properties of Vibrio species isolated from widely consumed seafood products. Int. J. Food Microbiol. 54: 9-18.

[16] InternationalDiseaseSurveillanceCenter (IDSC). 1999. Vibrio parahaemolyticus, Japan 1996-1998, Infectious Agents Surveillance Report (IASR), 20:1-2.

[17] Joseph SW, Colwell RR, Kaper JB (1982) Vibrio parahaemolyticus and related halophilic Vibrios. Crit. Rev. Microbiol. 10(1): 77-124.

[18] Kam KM, Leung TH, Ho YY, Ho NK, Saw TA (1995) Outbreak of Vibrio cholerae 01 in Hong Kong related to contaminated fish tank water. Public Health. 109(5): p. 389-395.

[19] Colwell RR (1996) Global climate and infectious diseases: the cholera paradigm. Sci. 274: 2025-2031.

[20] Ayulo AM, Machado R, Scussel V (1994) Entero toxigenic Escherichia coli and Staphylococcus aureus in fish and seafood from the southern region of Brazil. Int. J. Food Microbiol. 24:171-178.

[21] Chattopadhyay P (2000) Fish - catching and handling. In Robinson RK. Encyclopedia of Food Microbiol. London: Academic Press; 153 p.

[22] Asai Y, Murase T, Osawa R, Okitsu T, Suzuki R, Sata S, Terajima J,Izumiya H, Watanabe H (1999) Isolation of Shiga toxin-producing Escherichia coli O157:H7 from processed salmon roe associated with the outbreaks in Japan, 1998, and a molecular typing of the isolates by pulsed-field gel electrophoresis. Kansenshogaku Zasshi. 73: 2024. 
[23] Mitsuda, T; Muto, T; Yamada, M; Kobayashi, N; Toba, M; Aihara, Y; Ito, A; Yokota, S (1998) Epidemiological study of a food-borne outbreak of enterotoxigenic Escherichia coli $\mathrm{O} 25: \mathrm{NM}$ by pulsed-field gel electrophoresis and randomly amplified polymorphic DNA analysis. J. Clin. Microbiol. 36: 652-656.

[24] Vieira RHSF, Rodrigues DP, Gocalves FA, Menezes FGR, Aragao JS, Sousa OV (2001) Microbicidal effect of medicinal plant extracts (Psidium guajava Linn.and Carica papaya Linn.) upon bacteria isolated from fish muscle and known to induce diarrhea in children. Rev. Inst. Med. trop. S. Paulo 43 (3): 145-148.

[25] Pierard D, Crowcroft N, de Bock S, Potters D, Crabbe G,VLF, Lauwers S (1999) A casecontrol study of sporadic infection with $\mathrm{O} 157$ and non-O157 verocytotoxin-producing Escherichia coli. Epid. Infec. 122: 359-365.

[26] Semanchek JJ, Golden DA (1998) Influence of growth temperature on inactivation and injury of Escherichia coli O157:H7 by heat, acid, and freezing. J. Food Prot. 61: 395-401

[27] Isonhood JH, Drake M (2002) Aeromonas species in foods. J. Food Prot. 65: 575-582.

[28] Pogorelova NP, Zhuravleva LA, Ibragimov FKH, Iushchenko GV (1995) Bacteria of the genus Aeromonas as the causative agents of saprophytic infection. Zh Mikrobiol Epidemiol Immunobiol. 4: 9-12.

[29] Fernandes CF, Flick GJ, Thomas TB (1998) Growth of inoculated psychrotrophic pathogens on refrigerated fillets of aquacultured rainbow trout and channel catfish. J. Food Prot. 61(3): 313-317.

[30] Novotny L, Halouzka R, Matlova L, Vavra O, Dvorska L, Bartos M (2010) Morphology and distribution of granulomatous inflammation in freshwater ornamental fish infected with mycobacteria. J. Fish Dis. 33: 947-955.

[31] Olgunoğlu IA (2012) Salmonella in Fish and Fishery Products. In Mahmoud BSM. Salmonella - A Dangerous Foodborne Pathogen.: InTech; 2012.

[32] Heinitz ML, Ruble RD, Wagner DE, Tatini SR (2000) Incidence of Salmonella in fish and seafood. J. Food Prot. 63(5): 579-592.

[33] Vieira RHSF, Rodrigues DP, Gocalves FA, Menezes FGR, Aragao JS, Sousa OV (2001) Microbicidal effect of medicinal plant extracts (Psidium guajava Linn. and Carica papaya Linn.) upon bacteria isolated from fish muscle and known to induce diarrhea in children. Revista do Instituto de Medicina Tropical de São Paulo. 43:145-148.

[34] Eklund MW, Peterson ME, Poysky FT, Paranjpye RN, Pelroy GA (2004) Control of bacterial pathogens during processing of cold-smoked and dried salmon strips. J. Food Prot. 67: 347-351.

[35] Francis GA, O'Beirne D (1998) Effects of the indigenous microflora of minimally processed lettuce on the survival and growth of L. monocytogenes. Int. J. Food Sci. Tech. 33: 477-488.

[36] Alves VF, De Martinis ECP, Destro MT, Vogel BF, Gram L (2005) Antilisteral activity of a Carnobacterium piscicola isolated from brazilian smoked fish (Surubim (Pseudoplatystoma sp.)) and its activity against a persistent strain of Listeria monocytogenes isolated from surubim. J. Food Prot.11: 2068-2077. 
[37] Zunabovic M, Domig K, Kneifel W (2011)Practical relevance of methodologies for detecting and tracing of Listeria monocytogenes in ready-to-eat foods and manufacture environments - A review. LWT- Food Sci. Tech. 44(2): 351-362.

[38] Huss HH, Jørgensen LV, Vogel BF (2000) Control options for Listeria monocytogenes in seafoods. Int. J. Food Microbiol. 62(3): 267-74.

[39] Gudmundsdöttir S, Gudbjörnsdottir B, Lauzon H, Einarsson H, Kristinsson KG, Kristjansson M (2005) Tracing Listeria monocytogenes isolates from cold smoked salmon and its processing environment in Iceland using pulsed-field gel electrophoresis. Int. J. Food Microbiol. 101: 41-51.

[40] Bayles DO, Annous BA, Wilkinson BJ (1996) Cold stress proteins induced in Listeria monocytogenes in response to temperature downshock and growth at low temperatures. Appl. Environ. Microbiol. 62: 1116-1119.

[41] Miettinen H, Wirtanen G. Prevalence and location of Listeria monocytogenes in farmed rainbow trout (2005) Int. J. Food Microbiol. 104: 135-143.

[42] Tham W, Ericsson H, Loncarevic S, Unnerstad H, Danielsson-Tham ML (2000) Lessons from an outbreak of listeriosis related to vacuum-packed gravad and cold-smoked fish. Int. J. Food Microbiol. 62(3): 173-175.

[43] Fonnesbech Vogel B, Huss HH, Ojeniyi B, Ahrens P, Gram L (2001) Elucidation of Listeria monocytogenes contamination routes in cold-smoked salmon processing plants detected by DNA-based typing methods. Appl. Environ. Microbiol. 67(6): p. 2586-2595.

[44] Hoffman AD, Gall KL, Norton DM, Wiedmann M (2003) Listeria monocytogenes contamination patterns for the smoked fish processing environment and for raw fish. J. Food Prot. 66: p. 652-670.

[45] Thimothe J, Kerr Nightingale K, Gall K, Scott VN, Wiedmann M (2004) Tracking of Listeria monocytogenes in smoked fish processing plants. J. Food Prot. 67: 328-341.

[46] Peck MW(1997) Clostridium botulinum and the safety of refrigerated processed foods of extended durability. Trend.Food Sci. Tech. 8: 186-192.

[47] Hatheway CL (1995) Hath Botulism: the present status of the disease. Curr. Top. Microbiol. Imm. 195.

[48] Haagsma J. (1991) The distribution of Pathogenic anaerobic bacteria and the environment. Sci. Technic. Rev. Office Int. des. 10: 49-764.

[49] Sramova H, Benes C (1998) Occurrence of botulism in the Czech Republic (in Czech). Zpravy CEM (SZU Praha). 7: 395-397.

[50] Zhou GH, Xu XL, Liu Y (2010) Preservation technologies for fresh meat. Meat Sci. 86: 119-128.

[51] Devlieghere F, Vermeiren L, Debevere J (2004) New preservation technologies: Possibilities and limitations. Int. Dairy J.14: 273-285.

[52] Rodgers S (2001) Preserving non-fermented refrigerated foods with microbial cultures a review. Trends. Food Sci. Tech. 12: 276-284.

[53] Pilet MF, Leroi F (2011)Applications of protective cultures , bacteriocins and bacteriophages in fresh seafood and seafood product. In Lacroix C. Protective cultures, 
antimicrobial metabolites and bacteriophages for food and beverage biopreservation.: (C) 2011 Woodhead Publishing Limited.

[54] Galvez A, Abriouel H, Benomar N, Lucas R (2010) Microbial antagonists to food-borne pathogens and biocontrol. Cur. Opin. Biotech. 21: 142-148.

[55] Garcia P, Rodriguez L, Rodriguez A, Martinez B (2010) Food biopreservation:Promising strategies using bacteriocins, bacteriophage and endolysins. Trends. Food Sci. Tech. 373-382.

[56] Brillet A, Pilet MF, Prévost H, Cardinal M, Leroi F (2005) Effect of inoculation of inoculation of Carnobacterium divergens V41, a biopreservative strain against Listeria monocytogenes risk, on the microbiological, and sensory quality of cold-smoked salmon. Int. J. Food Microbiol. 104: 309-324.

[57] Pinto AL, Fernandes M, Pinto C, Albano H, Castilho F, Teixeira P, Gibbs PA (2009) Characterization of anti- Listeria bacteriocins isolated from shellfish. Int. J.Microbiol. 129: 50-58.

[58] Leroi F (2010) Occurrence and role of lactic acid bacteria in seafood products. Food Microbiol. 27: 698-709.

[59] Mozzi F, Raya RR, Vignolo GM, editors (2010) Biotechnology of Lactic Acid Bacteria: Novel Applications: Blackwell Publishing.

[60] Stiles E (1996) Biopreservation by lactic acid bacteria. Antonie van Leeuwenhoek. 70: 331-345.

[61] Ghanbari M, Rezaei M, Jami M, Nazari M (2010) Isolation and characterization of Lactobacillus species from intestinal content of Beluga(Huso huso) and persian sturgeon (Acipenser persicus). Iran. J. Vet. Res. 10(2): 152-157.

[62] Mayo B, Aleksandrzak - Piekarczyk T, Fernández M, Kowalczyk M, Álvarez - Martín P, Bardowski J (2010) Updates in the Metabolism of Lactic Acid Bacteria. In Mozzi F, Raya RR, Vignolo GM, editors. Biotechnology of Lactic Acid Bacteria: Novel Applications.: Blackwell Publishing.

[63] Ringo E, Gatesoupe F (1998) Lactic acid bacteria in fish: a review. Aquacult. 160: 177203.

[64] Hammes WP, Vogel RF (1995) The genus Lactobacillus Glasgow: Blackie Academic \& Professional.

[65] Duffes F, Corre C, Leroi F, Dousset X, Boyaval P (1999) Inhibition of Listeria monocytogenes by in situ produced and semipurifi ed bacteriocins of Carnobacterium spp. on vacuum-packed, refrigerated. J. Food Prot. 62: 394-1403.

[66] Campos C, Rodríguez O, Calo-Mata P, Prado M, Barros-Velazquez J (2006) Preliminary characterizationof bacteriocins from Lactococcus lactis, Enterococcus faecium and Enterococcus mundtii strains isolated from turbot (Psetta maxima ). Food Res. Int. 39: 35664.

[67] Drider D, Fimland G, Hechard Y, McMullen L, Prevost H (2006) The continuing story of class IIa bacteriocins. Microbiology and Molcular Biology Reviews. 70: 564 - 582. 
[68] Ouwehand A, Vesterlund S (2004) Antimicrobial Components from Lactic Acid Bacteria. In Salminen S, Wright v, Ouwehand A. Lactic Acid Bacteria Microbiological and Functional Aspects.: Marcel Dekker, Inc.

[69] Cotter PD, Hill C, Ross RP (2005) Bacteriocins: Developing innate immunity for food . Nat. Rev. Microbiol 3, $777-788$.

[70] Nes I, Yoon S, Diep D (2007) Ribosomally Synthesiszed Antimicrobial Peptides (Bacteriocins) in Lactic Acid Bacteria: A Review. Food Sci. Biotech.. 16(5): 675-690.

[71] Cotter PD, Draper LA, Lawton EM, McAuliffe O, Hill C, Ross RP (2006) Overproduction of wild-type and bioengineered derivatives of the lantibiotic lacticin 3147. Appl. Environ. Microbiol. 72, $4492-4496$

[72] Gillor O, Etzion A, Riley M (2008) The dual role of bacteriocins as anti- and probiotics. Appl. Microbiol. Biotech.. 81: 591-606.

[73] Nes I (2011) History, Current Knowledge, and Future Directions on Bacteriocin Research in Lactic Acid Bacteria. In Drider D, RS, (eds.). Prokaryotic Antimicrobial Peptides: From Genes to Applications.: Springer Science+Business Media, LLC p. 3-12.

[74] Lindgren SE, Dobrogosz WJ (1990) Antagonistic activities of lactic acid bacteria in food and feed fermentations. FEMS Microbiol. Lett. 87(1-2): 149-164.

[75] Podolak PK, Zayas JF, Kastner CL, Fung DYC (1996) Inhibition of Listeria monocytogenes and Escherichia coli O157:H7 on beef by application of organic acids. J. Food Prot. 59: 370-373.

[76] Ammor MS, Mayo B (2007) Selection criteria for lactic acid bacteria to be used as functional cultures in dry sausage production: An update. Meat Sci. 76: 138-146.

[77] Devlieghere F, Debevre J (2000) Influence of dissolved carbon dioxide on the growth of spoilage bacteria. Lebensmittel- und Wissenschaft-Technologie. 33: 531-537.

[78] Lanciotti E, Santini C, Lupi E, Burrini D (2003) Actinomycetes, cyanobacteria and algae causing tastes and odours in water of the River Arno used for the water supply of Florence. J. Water Sup. Res. Tech. 52(7): 489-500.

[79] Kvasnikov EI, Kovalenko NK, Materinskaya LG (1997) Lactic acid bacteria of freshwater fish. Microbiol. 46: 619-624.

[80] Cai Y, Suyanandana P, Saman P (1999) Classification and characterization of lactic acid bacteria isolated from the intestines of common carp and freshwater prawns. The J. Gen. Appl. Microbiol. 45: 177-184.

[81] Huss HH, Jeppesen VF, Johansen C, Gram L (1995) Biopreservation of fish products a reviewof recent approaches and results. J. Aquat. Food Prod. Tech. 4: 5-26.

[82] González CJ, Encinas JP, García-López ML, Otero A (2000) Characterization and identification of lactic acid bacteria from freshwater fishes. Food Microbiol. 17: 383-391.

[83] Bucio A, Hartemink R, Schrama JW, Verreth J, Rombouts FM (2006) Presence of lactobacilli in the intestinal content of freshwater fish from a river and from a farm with a recirculation system. Food Microbiol. 23(5): 476-482. 
[84] Ringo E, Strom E (1994) Microflora of Arctic char, Salvelinus alpinus (L.); gastrointestinal microflora of free-living fish, and effect of diet and salinity on the intestinal microflora. Aquacult. Fish. Manag. 25: 623-629.

[85] Ringo E (2004) Lactic acid bacteria in fish and fish farming. In Salminen S, Wright A, Ouwehand A, editors. Lactic acid bacteria : Microbiological and Functional Aspects. 3rd ed. New-York: CRC Press; 581-610.

[86] Ringø E, Strøm E, Tabachek JA (1995) Intestinal microflora of salmonids: a review. Aqua. Res. 26: 773-789.

[87] Ringø E, Olsen RE (1999) The effect of diet on aerobic bacterial flora associated with intestine of Arctic charr (Salvelinus alpinus L.). J. Appl. Microbiol. 86: 12-28.

[88] Spanggaard B, Huber I, Nielsen J, Nielsen T, Appel KF, Gram L (2000) The microflora of rainbow trout intestine. A comparison of traditional and molecular identification. Aquacult. 182: 1-15.

[89] Seppola M, Olsen RE, Sandaker E, Kanapathippillai P, Holzapfel W, Ringø E (2006) Random amplification of polymorphic DNA (RAPD) typing of carnobacteria isolated from hindgut chamber and large intestine of Atlantic cod (Gadus morhua L.). Sys. Appl. Microbiol. 29: p. 131-137.

[90] Gancel F, Dzierszinski F, Tailliez R (1997) Identification and characterization of Lactobacillus species isolated from fillets of vacuum-packed smocked and salted herring (Clupea harengus). J. appl. Microbiol. 82: 722-728.

[91] Magnússon H, Traustadóttir K (1982) The microbial flora of vacuum-packed smoked herring fillets. J. Food Tech. 17: 695-702.

[92] Paludan-Müller C, Dalgaard P, Huss H, Gram L (1998) Evaluation of the role of Carnobacterium piscicola in spoilage of vacuum and modified atmosphere-packedsmoked salmon stored at $5^{\circ} \mathrm{C}$. Int. J. Food Microbiol. 39: 155-166.

[93] Leroi F, Joffraud JJ, Chevalier F, Cardinal M (1998) Study of the microbial ecology of cold smoked salmon during storage at $8^{\circ} \mathrm{C}$. Int. J. Food Microbiol. 39: 111-121.

[94] Leisner J, Laursen B, Prevost H, Drider D, Dalgaard P (2007) Carnobacterium:positive and negative effects in the environment and in foods. FEMS Microbiol. Rev. 13: 592-613.

[95] Leisner JJ, Millan JC, Huss HH, Larsen LM (1994) Production of histamine and tyramine by lactic acid bacteria isolated from vacuum-packed sugar-salted fish. J. Appl. Bacter. 76: 417-423.

[96] Østergaard A, Ben Embarek PK, Wedel-Neergaard C, Huss HH, Gram L (1998) Characterization of anti-listerial lactic acid bacteria isolated from Thai fermented fish products. Food Microbiol. 15: 223-233.

[97] Olympia M, Ono H, Shinmyo A, Takano M (1992) Lactic acid bacteria in fermented fishery, burong bangus. J. Fer. Bioeng. 73(3): 193-197.

[98] Mauguin S, Novel G (1994) Characterization of lactic acid bacteria isolated from seafood. J. Appl. Bacter. 76 : 616-625. 
[99] Emborg J, Laursen BG, Rathjen T, Dalgaard P (2002) Microbial spoilage and formation of biogenic amines in fresh and thawed modified atmosphere-packed salmon (Salmo salar) at 2 degrees C. J. Appl. Microbiol. 92(4). 790-799

[100] Franzetti L, Scarpellini M, Mora D, Galli A (2003) Carnobacterium spp. in seafood packaged in modified atmosphere. Annal. Microbiol. 53: 189-193.

[101] Emborg J, Laursen BG, Rathjen T, Dalgaard P (2002) Microbial spoilage and formation of biogenic amines in fresh and thawed modified atmosphere-packed salmon (Salmo salar) at $2^{\circ} \mathrm{C}$. J. Appl. Microbiol. 92: 790-799.

[102] Dalgaard P, Madsen HL, Samieian N, Emborg J (2006) Biogenic amine formation and microbial spoilage in chilled garfish (Belone belone) effect of modified atmosphere packaging and previous frozen storage. J. Appl. Microbiol. 101: 80 - 95.

[103] Lakshmanan R, Dalgaard P (2004) Effect of high-pressure processing on Listeria monocytogenes, spoilage microflora and multiple compound quality indices in chilled cold-smoked salmon. J. Appl. Microbiol. 96: 398-408.

[104] Wessels S, Huss HH (1996) Suitability of Lactococcus lactis ATCC 11454 as a protective culture for lightly preserved fish products. Food Microbiol. 13: 323-332.

[105] Nilsson L, Ng YY, Christiansen JN, Jorgensen BL, Grotinum D, Gram L (2004) The contribution of bacteriocin to inhibition of Listeria monocytogenes by Carnobacterium piscicola strains in cold-smoked salmon systems. J. Appl. Microbiol. 96: 133-143.

[106] Altieri C, Speranza B, Del Nobile MA, Sinigaglia M (2005) Suitability of bifidobacteria bacteria and thymol as biopreservatives in extending the shelf life of fresh packed plaice fillets.. J. Appl. Microbiol. 99: 1294-1302.

[107] Yin LJ, Wu CW, Jiang ST (2007) Biopreservative effect of pediocin ACCEL on refrigerated seafood. Fish. Sci. 73: 907-912.

[108] Ringo E (2008) The ability of carnobacteria isolated from fish intestine to inhibit growth of fish pathogenic bacteria. Aqua. Res. 39: 171-180.

[109] Sudalayandi, K.M (2011) Efficacy of lactic acid bacteria in the reduction of trimethylamine-nitrogen and related spoilage derivatives of fresh Indian mackerel fish chunks. Afr. J. Biotech. 10: 42-47.

[110] Kim CR, Hearnsberger JO (1994) Gram negative bacteria inhibition by lactic acid culture and food preservatives on catfish fillets during refrigerated storage. J. Food Sci. 59: 513-516.

[111] Einarsson H, Lauzon HL (1995) Biopreservtaion of brined shrimp (Pandalus borealis) by bacteriocins from lactic acid bacteria. Appl. Environ. Microbiol. 61: 669-675.

[112] Morzel M, Fransen NG, Arendt EK (1997) Defined starter cultures for fermentation of salmon fillets. J. Food Sci. 62(6): 1214-1217.

[113] Kışla D, Ünlütürk A (2004) Microbial shelf life of rainbow trout fillets treated with lactic culture and lactic acid. Adv. Food Sci. 26: 17-20.

[114] Elotmani F, Assobhei O (2004) In vitro inhibition of microbial flora of fish by nisin and lactoperoxidase system. Lett. Appl. Microbiol. 38: 60-65. 
[115] Aras Husar S, Kaban G, Husar O, Yanik T, Kaya M (2005) Effect of Lactobacillus sakei Lb706 on Behavior of Listeria monocytogenes in Vacuum-Packed Rainbow Trout Fillets. Tur. J. Vet. Anim. Sci. 29: 1039-1044.

[116] Kim Y, Ohta T, Takahashi T, Kushiro A, Nomoto K, Yokokura T, Okada N, Danbara H (2006). Probiotic Lactobacillus casei activates innate immunity via NF- $\mathrm{B}$ and p38 MAP kinase signaling pathways. Microb. Infec.. 8: 994-1005.

[117] Katikou P, Ambrosiadis IGD, Koidis P, Georgakis SA 2(2007) Effect of Lactobacillus cultures on microbiological, chemical and odour changes during storage of rainbow trout fillets. J. Sci. Food Agri. 87: 477-484.

[118] Daboor SM, Ibrahim SM (2008) Biochemical and microbial aspects of tilapia (Oreochromis niloticus L.) biopreserved by Streptomces sp. metabolites. In $4^{\text {th }}$ International Conference of Veterinary Research Division, National Research Center (NRC); Cairo, Egypt. p. 39-49.

[119] Tahiri M, Desbiens E, Kheadr C, Lacroix IF (2009) Comparison of different application strategies of divergicin M35 for inactivation of Listeria monocytogenes in cold-smoked wild salmon. Food Microbiol. 26: p. 783-793.

[120] Matamoros S, Pilet MF, Gigout F, Prévost H, Leroi F (2009) evaluation of seafoodborne psychrotrophic lactic acid bacteria as inhibitors of pathogenic and spoilage bacteria. Food Microbiol. 26: 638-644.

[121] Fall PA, Leroi F, Cardinal M, Chevalier F, Pilet MF (2010) Inhibition of Brochothrix thermosphacta and sensory improvement of tropical peeled cooked shrimp by Lactococcus piscium CNCM I-4031. Lett. Appl. Microbiol. 50: 357-361.

[122] Ibrahim SM, Salha GD (2009) Effect of antimicrobial metabolites produced by lactic acid bacteria on quality aspects of frozen Tilapia (Oreochromis niloticus) fillets. World Journal of Fish and Marine Sciences. 1: 40-45.

[123] Shirazinejad AR, Noryati I, Rosma A, Darah I (2010) Inhibitory Effect of Lactic Acid and Nisin on Bacterial Spoilage of Chilled Shrimp. World Acad. Sci. Eng. Tech.

[124] Fall PA, Leroi F, Chevalier F, C G, Pilet MF (2010) Protective effect of a nonbacteriocinogenic Lactococcus piscium CNCM I-4031 strain against Listeria monocytogenes in sterilised tropical cooked peeled shrimp. J. Aquat. Food Prod. Tech. 19: 84-92.

[125] Cosansu S, Mol S, Ucok Alakavuk D, Tosun ŞY (2011) Effects of Pediococcus spp. on the quality of vacuum-packed Horse Mackerel during Cold Storage. J. Agri. Sci. 17: 59-66.

[126] Katla T, Moretro T, Aasen IM, Holck A, Axelsson L, Naterstad K (2001) Inhibition of Listeria monocytogenes in cold smoked salmon by addition of sakacin $\mathrm{P}$ and/or live Lactobacillus sakei cultures. Food Microbiol. 18: 431-439.

[127] Blom H, Katla T, Hagen BF, Axelsson L (1997) A model assay to demonstrate how intrinsic factors affect diffusion of bacteriocins. Int. J. Food Microbiol. 38: 103-109.

[128] Brurberg MB, Nes IF, Eijsink VGH (1997) Pheromone-induced production of antimicrobial peptides in Lactobacillus. Mol. Microbiol. 26: 347-360.. 
[129] Eijsink VGH, Skeie M, Middelhoven H, Brurberg MB, Nes IF (1998) Comparative studies of pediocin-like bacteriocins.. Appl. Environ. Microbiol. 64: 3275-3281.

[130] Ganzle MG, Weber S, Hammes WP (1999) Effect of ecological factors on the inhibitory spectrum and activity of bacteriocins. Int. J. Food Microbiol. 46: $207-217$.

[131] Aasen IM, Moretro T, Katla T, Axelsson L, Storro I (2000) Infuence of complex nutrients, temperature and $\mathrm{pH}$ on bacteriocin production by Lactobacillus sakei CCUG 42687. Appl. Microbiol. Biotech.. 53: 159-166.

[132] Leroi F, Arbey N, Joffraud J, Chevalier F (1996) 'Effect of inoculation with lactic acid bacteria on extending the shelf-life of vacuum-packed cold-smoked salmon. Int. J. Food Sci. Tech. 1996; 31: p. 497-504.

[133] Budu-Amoako B, Albert RF, Harris J, Delves-Broughton J (1999) Combined effect of nisin and moderate heat on destruction of Listeria monocytogenes in cold-pack lobster meat. J. Food Prot. 62: 46-50.

[134] Nilsson L, Gram L, Huss H (1999) Growth control of Listeria monocytogenes on cold smoked salmon using a competitive lactic acid bacteria flora. J. Food Prot. 62: 336-342.

[135] Nykanen A, Weckman K, Lapvetelainen A (2000) Synergistic inhibition of Listeria monocytogenes on cold-smoked rainbow trout by nisin and sodium lactate. Int. J. Food Microbiol. 61: 63-72.

[136] Silva J, Carvalho AS, Teixeira P, Gibbs PA (2002) Bacteriocin production by spraydried lactic acid bacteria. Lett. Appl. Microbiol. 34(2): 77-81.

[137] Bouttefroy A, Millière JB (2000) Nisin-curvaticin 13 combinations for avoiding the regrowth of bacteriocin resistant cells of Listeria monocytogenes ATCC 15313. Int. J. Food Microbiol. 62: 65-75.

[138] Yamazaki K, Suzuky M, Kawai Y, Inoue N, Montville TJ (2003) Inhibition of Listeria monocytogenes in cold-smoked salmon by Carnobacterium piscicola CS526 isolated from frozen surimi. J. Food Prot. 66: 1420-1425.

[139] Yamazaki K, Suzuki M, Kawai Y,IN, Montville TJ (2005) Purification and characterization of a novel class IIa bacteriocin, piscicocin CS526, from surimi associated Carnobacterium piscicola CS526. Appl. Environ. Microbiol. 71: p. 554-557.

[140] Brillet A, Pilet MF, Prevost H, Bouttefroy A, Leroi F (2004). Biodiversity of Listeria monocytogenes sensitivity to bacteriocin-producing Carnobacterium strains and application in sterile cold-smoked salmon. J. Appl. Microbiol. 97: 1029-1037.

[141] Weiss A, Hammes WP (2006) Lactic acid bacteria as protective cultures against Listeria spp. on cold-smoked salmon. Eur. Food Res. Tech. 222: 343-346.

[142] Vescovo M, Scolari G, Zacconi C (2006) Inhibition of Listeria innocua growth by antimirobial-producing lactic acid cultures in vacuum-packed cold-smoked salmon. Food Microbiol. 23: 689-693.

[143] Laursen BG, Bay L, Cleenwerck I, Vancanneyt M, Swings J, Dalgaard P (2005). Carnobacterium divergens and Carnobacterium maltaromicum as spoilers or protective cultures in meat and seafood: phenotypic and genotypic characterisation. Sys. Appl. Microbiol. 28: 151-164. 
[144] Tomé E, Pereira VL, Lopes CI, Gibbs PA, Teixeira PC (2008) In vitro tests of suitability of bacteriocin-producing lactic acid bacteria, as potential biopreservation cultures in vacuum-packaged cold-smoked salmon. Food Control. 19: 535-543.

[145] Matamoros S, Leroi F, Cardinal M, Gigout F, Kasbi Chadli F, Cornet J, Prevost F, Pilet M.F (2009). Psychrotrophic lactic acid bacteria used to improve the safety and quality of vacuum-packaged cooked and peeled tropical shrimp and cold smoked salmon. J. Food Prot. 72: 365-374. 